\title{
CONCEALED CHARACTER VALUES ON LECTURERS' VERBAL FEEDBACK IN ENGLISH TEACHING
}

\author{
Adetya Norizkyka ${ }^{1}$,Yulieda Hermaniar ${ }^{2}$ \\ ${ }^{1}$ Universitas Ahmad Dahlan Yogyakarta, Indonesia \\ ${ }^{1}$ norizkykaa@gmail.com \\ ${ }^{2}$ STKIP PGRI Banjarmasin, Indonesia \\ 2 yuliedahermaniar@stkipbjm.ac.id
}

\begin{abstract}
Integrating values in the teaching and learning of English becomes the main concern of education in Indonesia. There are 18 values of character building in national character and cultural education which are demanded to be integrated in the teaching and learning process. However, the implementation is mostly heard from lower level of education. Therefore, it is considered important to conduct the study on the higher level of education or university, especially in the productive course such as speaking class. This leads to the interest on conducting study on the lecturers' verbal feedback in English teaching as the reflection of teaching character values. Preliminary study was conducted by interviewing students of speaking class to get information related to the technique, method, and material used in the speaking class. Three speaking class' lecturers will be the subject of the research. Observation is conducted to collect the data by using observation sheet and recorder as instrument. The interview takes students as the object in order to get their perspective to the feedback give. The result shows that there are three kinds of verbal feedback used. They are corrective feedback, interactive feedback, and evaluative feedback. The result of interview shows students positive perspective toward the feedback and the values they acquired from the feedback give. From the observation and interview, it can be concluded that the concealed values taught during the speaking class, they are disciplines, curious, respect, democracy, and communicative.
\end{abstract}

Keywords: character values, English speaking class, verbal feedback

\section{INTRODUCTION}

As a part of English teaching in Indonesia, classroom interaction takes an important part. The classroom is a condition in which students can improve their ability in learning English, that is a condition which is like the real communication, should be the place for interaction and communication among students, either in oral or written forms. Communication in the classroom can be built by interaction. According to Brown (2001:165), interaction is collaborative exchange of thoughts, feelings, or ideas between two or more people (students and teacher or students and students), resulting in reciprocal effect in each other.

Among the four skills in English, speaking takes a significant role in underlining the idea of verbal feedback communication, as Nunan (1999:54) said "Speaking is the most important aspect of learning a second language". Speaking makes students interact each other to use English verbally. In speaking, students get the opportunity to increase their ability in an attractive way. However, errors mostly happen in practicing this skill. Hence, it is considered necessary for the students to get feedback that makes them aware of the error. Feedback is also seen to provide information about how to avoid doing the same mistakes again. Therefore, in pointing out the errors done by students, it is necessary to give feedback.

Lecturers' feedback has a positive effect on oral accuracy. The important thing from feedback is not only transferring the knowledge but also stimulating students' participation. It is supported by Prof. Y.K. Ip (2008) "The knowledge that they 
absorb well gives the students a sense of achievement which motivates them to learn more". When the interaction occurs, students have more opportunity to learn a language. Students also easily get checked from their lecturers about proficiency in learning the second language and students can increase their language mastery during classroom activities.

Teachers and lecturers basically have the same nature in terms of education symbol of learning to guide the learners as a leader of our educational journey. They educate us with all of their knowledge and knows mostly all the answers. The discussion under the topic of feedback has been discussed by Idris Aman (2010:25), a student of Kebangsaan Malaysia University she did her research about Teachers's Verbal Feedback on Students' Response: A Malaysian ESL Classroom Discourse Analysis. Students' reactions and attitudes to teacher feedback are an intricate matter, intertwined not only with students' proficiency level, teacher factors, such as teachers' beliefs and practices and their interactions with the students, as well as in the context of feedback.

During the interaction, there are numerous ideas shared, information gathered, and values achieved. In line with the current issue of character building, character education is considered important as it becomes the main concern of education in Indonesia. There are 18 values of character building in national character and cultural education such as; religious, honesty, tolerance, discipline, work hard, creative, independent, democracy, curious, nationality, loving the nation, sportive and respect, inclusion / communicative, loving peace, love reading, care and compassion, empathy, and responsibility. Since character building is not mentioned explicitly in the material, teachers were demanded to integrate it in the lesson plan. This leads to the interest on conducting study on carrying out the lecturers' verbal feedback in English teaching as well as how the lecturers integrate the values education in the classroom.

\section{LITERATURE REVIEW}

2.1 The Concept of Feedback

Feedback is conceptualized as information provided by an agent (e.g, teacher, peer, book, parent, self and experience) regarding aspects of one's performance or understanding. According to Ellis and Susanna (1999:702), feedback in teachingstudents learning environment can be defined as "information given to learners which they can use to revise their inter language". Winnne and Butler (1994:5740) provided an excellent summary in their claim that "feedback is information with which learner can confirm, add to, overwrite, tune, or restructure information in memory, whether that information is domain knowledge, meta-cognitive knowledge, beliefs about self and tasks, or cognitive tactics and strategies".

2.2 Types of Feedback

There are three types of feedback; they are evaluative feedback, interactive feedback, and corrective feedback. Evaluative feedback aims to provide a judgment on the students' performance. Gattullo (2000) and Hanoi (2011) suggest that feedback is dominant in second and foreign language classroom. In giving evaluative feedback, teachers use words and phrases to indicate the extent to which students' performance is good or not. Finally, evaluative feedback usually aims to offer students advice on what to do to improve their performance. In other word, the lecturer tries to suggest ways of helping students to overcome their mistakes.

Richard and Lockhart (1996) identified 'interactional feedback' as a strategy to expand or modify a student's answer. In this case, Interaction with students 
involves providing feedback and encouraging 2-way dialogue with students and this exercise helps the lecturers to deliver this on a number of different levels. By encouraging students to guess at the results (as opposed to simply relaying them), we are often able to prove that significant gaps appear in what they believe is happening among their peers and the often 'positive' majority recorded behaviour. The exercise is also useful for facilitating discussions about why myths about risk taking behaviour participation exist - or offer further insights and discussion into the topic area itself.

Corrective feedback focuses on helping learners notice and correct errors. This type of feedback explains why responses are correct or wrong. In learning speaking, corrective feedback will primarily concern with accuracy. According to Lyster \& Ranta (1997) put forward six types of corrective feedback. The six types are: Explicit correction: teachers supply the correct form and clearly indicate that what the students say is incorrect, Recast: teacher implicitly reformulates all or part of the students' utterance, Elicitation: lecturer directly elicits a asking questions or by pausing to allow students to complete lecturer's utterance, or asking students to reformulate their utterance, Metalinguistic feedback: to the well-formedness of the student's utterance, Clarification request: lecturer's request for further information from a student about a previous utterance, Repetition: lecturer repeats the student's ill-formed utterance, adjusting intonation to highlight the error.

2.3 Effect of Feedback

There are reasons why feedback can be an effective way for students to draw conclusion on how to achieve a better knowledge of a second language. There are several components that can have an effect on the student's uptake. Uptake refers to "a learner's immediate response to corrective feedback on his/her utterances" (Lightbown \& Spada, 1999:179), while corrective feedback is used as "an indication to a learner that his or her use of the target language is incorrect" (Lightbown \& Spada, 1999:172).The approach chosen by the teacher, the atmosphere, and the type of situation in which the speaking performance is taking place will influence the effectiveness of feedback.

According to Van-Dijk and Kluger (2001:23)demonstrates that positive feedback increases motivation relative to negative feedback for a task that people "want to do" and decreases motivation relative to negative feedback for a task that people "have to do." Thus, when we are committed to a goal, we are more likely to learn as a function of positive feedback.

Positive feedback can increase the likelihood that students will return to or persist in an activity and self-report higher interest in the activity (Deci et al.,1999). There is also an interaction effect at this level between positive and negative feedback and the self-efficacy of students. Swann and Pelham (1988) found that for highly self-efficacious students, feedback about initial success may signify a talent or potential ability, which leads to better coping in the face of disconfirmation feedback. They related the feedback to positive verifications of themselves as learners. As a consequence of disconfirmation feedback, highly self-efficacious people make more optimistic predictions about their performance after initial failure than after initial success, and they seek specifically unfavorable feedback to excel at the tasks. 


\section{METHODS}

\subsection{Research Method}

This study uses descriptive method in which the focus of the research is providing the description of types of verbal feedback employed by the lecturers, types of lecturer's verbal feedback is most frequently employed, the students' response of the feedback, and carry out the values which are implicitly learned during the feedback given.

\subsection{Subject}

The subjects are the lecturers of speaking III classes at the English Department of Lambung Mangkurat University who have 2 to 20 years of teaching experience. There are 3 lecturers of speaking III class, lecturer A teaches A class, lecturer B teaches $\mathrm{B}$ class, and lecturer $\mathrm{C}$ teaches $\mathrm{C}$ class.

\subsection{Research Instrument}

Two kinds of instruments are used in order to gather the data. To collect the qualitative data related to verbal feedback in the teaching and learning process, observation sheet is used, while tape recorder is used to record the interview. The interview is held right after the observation to the students who are the subject of feedback in the classroom.

\subsection{Technique of Data Analysis}

The data in this research is being analyzed qualitatively. In analyzing the data that has been collected, the researcher uses some steps as follow:

a. Listening to the data that has been recorded from the tape recording.

b. After the observation in the classroom, the researcher is listening the recording of lecturers' feedback in the classroom.

c. Transcribing the data that has been collected from the recording into written from.

d. The recording has been listened, after that the researcher transcribes the data into written form.

e. Classifying the data that has been collected.

f. After the researcher list the data into field note, then she classifies the data into forms of feedbacks, evaluative feedback, and interactive feedback.

g. Putting the data has been collected into the tables.

h. When all the data have been classified into forms of feedbacks, worksheet table of corrective feedback, interactive feedback and evaluative feedback. This tabulation is done to get the pattern of feedbacks in students' performance at Speaking III class of English Department in Lambung Mangkurat University Academic Year 2014/2015.

i. Discussing and summarizing the findings.

j. After all the steps above, it is time to discuss the findings in detail.

\section{FINDINGS AND DISCUSSION}

4.1. Findings

4.1.1 The Result of Observation

Based on the observation, there are 3 types of feedbacks given by lecturers during the observation of teaching and learning. The details of feedback are presented as follows:

a. Corrective Feedback

To know the expression of corrective feedbacks from different lecturers, the researcher makes a worksheet. The result is presented on the following table. 
Table 1: Worksheet of Corrective Feedback

\begin{tabular}{clll}
\hline No & \multicolumn{1}{c}{ Lecturer A } & \multicolumn{1}{c}{ Lecturer B } & \multicolumn{1}{c}{ Lecturer C } \\
\hline 1 & What? & Weapon & Yes, should confidence \\
2 & again please & Reaction & Yes, make it on board \\
3 & awesome & Fifty years & \\
4 & generation & Increase & \\
5 & easiest way & Weather & \\
6 & change & It's very nice topic & \\
7 & foreigner & & \\
\hline
\end{tabular}

Based on the table above, we could see that the lecturers gave different forms of feedbacks. However, they made the same form of feedbacks in correcting pronunciation. In this table, the lecturer corrected error and pronunciations. Mostly, corrective feedbacks were in the form of imperative.

Although all lecturers gave varied expression of corrective feedbacks, but actually all of them had the same characteristics. The characteristics of corrective feedback were when the lecturer explained why it is correct or wrong. Corrective feedback focused on helping learners to notice and correct the errors.

Among all the lecturers, they have done corrective feedback by correcting the error and pronunciation. The followings are the examples of corrective feedback:

$\mathrm{S}$ : if we can make good generation. We can change..

$\mathrm{L}$ : we can what?

$\mathrm{S}:$ we can ceng the future..

$\mathrm{L}$ : change! /'t $\int \mathrm{e}$ indz/

b. Interactive Feedback

To know the expression of corrective feedbacks from different lecturers, the researcher makes a worksheet. The result is presented on the following table.

Table 2: Worksheet of Interactive Feedback

\begin{tabular}{clll}
\hline No & \multicolumn{1}{c}{ Lecturer A } & \multicolumn{1}{c}{ Lecturer B } & \multicolumn{1}{c}{ Lecturer C } \\
\hline 1 & What do you mean? & Why do I...? & What kind of... \\
2 & What do you say? & How can you..? & Do you think.. \\
3 & What do you think? & What do you think? & Why it... \\
4 & What did you.. & & What else? \\
5 & & & Do you have..? \\
6 & & & How about...? \\
\hline
\end{tabular}

Based on the table above, it could be seen that the lecturers gave the same form of feedback. The characteristics of interactive feedback used the word 'what' and 'how'. All lecturers gave different interactive feedback in the form of 'what'. The characteristics were when lecturers expanded or modified the students' answers. Interactive feedback is mostly given are "what do you think?"

Richard and Lockhart (1996) identified 'interactional feedback' as strategy to expand or modify the students' answers. Among all the lecturers, they have done the interactive feedback by interrogating the word 'what'. The followings are the form of interactive feedback:

$\mathrm{S}:$ scarf sasirangan

$\mathrm{L}:$ what do you mean?

$\mathrm{S}$ :kerudung

L : you make it difficult, you can wear..

$\mathrm{S}$ : you can wear..

$\mathrm{L}$ :sasirangan headscarf! 
c. Evaluative Feedback

To know the expression of corrective feedbacks from different lecturers, the researcher makes a worksheet. The result is presented on the following table.

Table 3: Worksheet of Evaluative Feedback

\begin{tabular}{|c|c|c|c|}
\hline No & Lecturer A & Lecturer B & Lecturer C \\
\hline 1 & Basic-nyadulu & Remember for the & That's right \\
\hline 2 & You don't need to.. & speaker & Yes of course.. \\
\hline 3 & Not last season but... & Keep your manner & You don't need to... \\
\hline 4 & You should say.. & Be better next time & You can use.. \\
\hline 5 & & & You need to know.. \\
\hline
\end{tabular}

Based on the table above, it could be seen that between lecturer A and C had the same sentence in giving feedback, but they had the same characteristics with lecturer B. All lecturers gave many kinds of evaluative feedbacks. The characteristic of evaluative feedback was when lecturer repeated students' error and adjusts intonation. All the lecturers have done the evaluation feedback by repeating students" error and adjust intonation. Evaluative feedbacks mostly given are "you don't need to".

Evaluative feedback is supposed to judgment on the students' performance. In giving evaluative feedback, teachers used words and phrases to indicate the extent to which students' performance is good or not. In other case, the lecturer tried to suggest ways of helping students to overcome their mistakes. The characteristic of evaluative feedback was when lecturer repeated students' error and adjusts intonation.

All the lecturers have done the evaluation feedback by repeating students' error and adjust intonation. The followings are the form of evaluative feedback:

S : oh sorry, my question is do you love travelling? Have you got 3 thing basic that you...

$\mathrm{L}$ :basic nya dulu

$\mathrm{S}$ : have you got basic 3 thing when you are travelling?

\subsubsection{The Result of Interview}

The Interview is held after the observation with the students who are the object of the feedback. The questions are focused on what values acquired from the feedback given. The list of the questions is presented on table 4 and students' answers are presented on the table 5. On the second question of interview, the researcher shows list of character values to the students so their answers focus on describing the values.

Table 4: List of Interview Questions

\begin{tabular}{cl}
\hline No. & \multicolumn{1}{c}{ Questions } \\
\hline 1. & Apakah menurut kamu feedback itu penting? \\
2. & Apa nilai-nilai kamu dapat dari pemberian feedback yang diberikan? Jelaskan \\
& kenapa.
\end{tabular}


Table 5: The Result of Interview

\begin{tabular}{|c|c|c|c|}
\hline Questions & Corrective Feedback & Interactive Feedback & Evaluative Feedback \\
\hline 1 & $\begin{array}{l}\text { Penting, apalagi tadi } \\
\text { kan soal pronunciation, } \\
\text { kalau diingatkan seperti } \\
\text { itu jadi langsung ingat } \\
\text { terus. }\end{array}$ & $\begin{array}{l}\text { Iya, kalau dibiarkan nanti } \\
\text { salah terus. }\end{array}$ & $\begin{array}{l}\text { Penting. Jadi ada gambaran } \\
\text { buat presentasi topkc } \\
\text { selanjutnya ralahnya } \\
\text { dimana. Yang jadi } \\
\text { listenernya juga jadi aware. }\end{array}$ \\
\hline 2 & $\begin{array}{l}\text { Discipline } \\
\text { karena saya diharuskan } \\
\text { segera memperbaiki } \\
\text { yang salah tadi. } \\
\text { Independent, karena } \\
\text { gaada yang bantu saya } \\
\text { memperbaiki, kan } \\
\text { feedbacknya direct. }\end{array}$ & $\begin{array}{l}\text { Democracy } \\
\text { Feedbacknya tadi } \\
\text { dialog jambil } \\
\text { mendengarkan dan } \\
\text { berpendapat. }\end{array}$ & $\begin{array}{l}\text { Currious } \\
\text { Saya jadi penasaran aja apa } \\
\text { komentar dosen ke speech } \\
\text { saya karena semua yang } \\
\text { maju dikasih komentar } \\
\text { sesudahnya. Jadi pas giliran } \\
\text { saya, menunggu itu. }\end{array}$ \\
\hline & 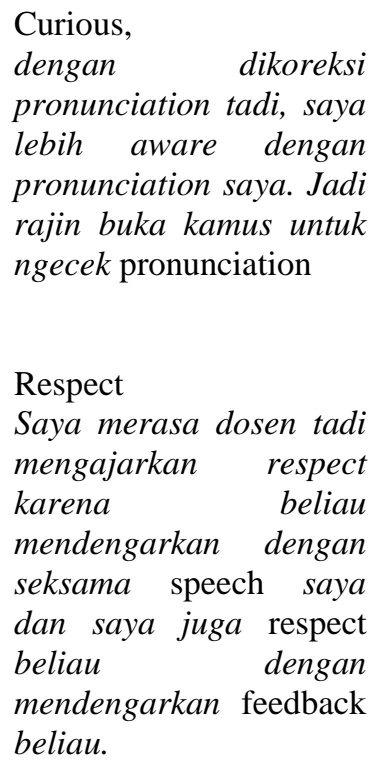 & $\begin{array}{l}\text { Communicative } \\
\text { Kaarena sambil dialog } \\
\text { jadi ada interaksi dua } \\
\text { belah pihak. Tidak melulu } \\
\text { saya yang mendengarkan } \\
\text { beliau, ataur beliau } \\
\text { mendengarkan speech } \\
\text { saya saja. }\end{array}$ & $\begin{array}{l}\text { Discipline } \\
\text { Saya sudah tau metode } \\
\text { mengajar dosennya seperti } \\
\text { apa, komentar-komentar } \\
\text { yang diberikan ke } \\
\text { mahasiswa yang sudah maju } \\
\text { duluan jadi saya sambil } \\
\text { latihan, sambil mengira- } \\
\text { ngira apa saja komentar } \\
\text { beliau nanti. }\end{array}$ \\
\hline
\end{tabular}

\subsection{Discussion}

By classifying the types of feedback, it can be concluded that students acquire different values from different types of feedback. Corrective and interactive feedback offers three values when they are compared to evaluative feedback. The corrective and interactive feedback naturally offers the same nature; they are direct and open the room for discussion. In the corrective feedback, the situation happens when the students pronounce certain word wrong and the lecturer immediately correct by not saying it's wrong, but by saying the correct pronunciation. Without pointing out the mistake, this kind of feedback can be concluded as positive feedback since it builds the awareness of the students to correct her pronunciation right away as stated by Van-Dijk and Kluger (2001:23) that positive feedback increases motivation relative to negative feedback for a task that people "want to do" and decreases motivation relative to negative feedback for a task that people "have to do." In some way, the motivation is in line with the spirit of values education in which the students are able to carry out the value by themselves.

Evaluative feedback, however, doesn't not offer the value of interaction since it is delivered at the end of the lesson. Evaluative feedback is intended to summary and gives overview on today's lesson as it focuses on helping learners notice and correct errors. This type of feedback explains why responses are correct or wrong. 
Even though this type of feedback is not direct feedback, but it doesn't mean that it's not important. Based on the student's respond on the interview, some values are carried. The student mentions curious and discipline since evaluative feedback offers the lecturer to talk more and deeper toward the errors. From the feedback, students may take note on the underlined point of the feedback and they can practice by predicting lecturer's comment. This is in line with Swann and Pelham (1988) who stated that more optimistic predictions about their performance after initial failure than after initial success, and they seek specifically unfavorable feedback to excel at the tasks.

So far, character education is still taught implicitly. Students acquired the values by doing the activity designed by the lecturer. Students somehow are not aware to the hidden values since they are not explicitly mentioned or discussed in the classroom so that their respond to the interview is also limited.

\section{CONCLUSION}

Verbal Feedback is considered as one of the activity which can stimulate students' awareness to errors made during speaking class. The types of feedback carry out various interaction as well as values learned during the process of teaching and learning. The values acquired by the student from the feedback given in the speaking class are disciplines, curious, respect, democracy, and communicative.

\section{REFERENCES}

Brown, H., D. (2001). Teaching By Principles. Upper Saddle River, NJ: Prentice Hall.

Ip, Professor Y.K. 2010.The Importance of Giving Feedback to Students.Department of Biological Sciences.

Nunan, David. 1999. Second Language Teaching and Learning. USA: An International Thomson Publishing Company.

Rod, Ellis. 2009. Corrective Feedback and Teacher Development.L2 Journal, 1 (1). California: University of California.

Rydahl, Susanna. 2005. Oral Feedback in the English Classroom Teachers' Thought and Awareness. Karlstads: KarlstadsUniversitet.

Salima, AyacheRabehi. 2014. Teachers' Oral Feedback impact on EFL Students' Oral Proficiency: Case Undergraduate classes of the English Branch at MKU-BISKRA. Kuala Lumpur:Mohammed Khider University.

Van, Tom Tat Luan. 2011. Effects of Teacher's Feedback on Freshmen's Motivation in Speaking Lessons: A Survey Research at Hanoi University of Business and Technology. Hanoi: Vietnam National University. 